\title{
Hukum Bukanlah Idealisasi Moral Masyarakat
}

\author{
Suparman Marzuki
}

The incompatibility of Indonesian legal system with the effort for creation of justice and economic welfare, closely links to the conceptual ground and integralistic state framework which strongly leads to give more power for the state, and not for the society. The solution needed is to push the law to further move from repressive law system toward autonomous law or responsive law.

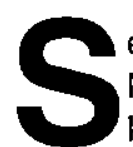

eorang ahli sosiologi hukum, David M. Trubek (1972) pernah melontar kan suatu pertanyaan yang menyudutkan: "apakah hukum sudah mati?". Pertanyaan Trubek yang menusuk itu dikemukakan dalam hubungannya dengan kesangsiannya mengenai kemampuan hukum untuk menyelesaikan persoalanpersoalan yang dihadapkan padanya; termasuk kegalauan Trubek melihat "tingkah laku" hukum yang acapkali mendatangkan persoalan ketimbang mengatasi persoalan. Meski kegelisahan dan kegalauan pada hukum yang melanda masyarakat kita sekarang ini tidak persis sama seperti sumber keresahan yang menyebabkan Trubek melontarkan pertanyaan tersebut, tetapi pertanyaan itu tetap relevan untuk diajukan menanggapi lemahnya hukum dan penegakan hukum kita beserta segenap instrumen pelaksanaannya di dalam menegakkan keadilan, ketertiban, keamanan dan kesejahteraan sosial masyarakait

Fenomena ketidakberpihakan hukum kepada rakyat sesungguhnya bukan khas Indonesia, tetapi juga terjadi pada kebanyakan negara-negara dunia ketiga. Menurut para ahli dari international Center for Law in Development (Garuda Nusantara, 1981) dinyatakan bahwa pada umumnya sistem hukum dan administrasi di banyak negara dunia ketiga justru merupakan sumber timbulnya ketidakadilan sosial. Hal itu disebabkan oleh: (1) perangkat perundang-undangan dan peraturan pelaksanaannya yang merupakan pedoman bagi pelaksana pembangunan, gagal untuk memenuhi tuntutan-tintutan kebutuhan dasar menusia, dan kegagalan ini mempengaruhi para pelaksana pembangunan dalam mengambil kebijaksanaan-kebijaksanaan tertentu; (2) bahwa hukum telah gagal dalam memberikan tempat bagi partitipasi masyarakat dalam institusi-institusi pelaksana pembangunan, 
dan kegagalan inj mempengaruhi persepsi birokrasi terhadap masalah-masalah dan isu-isu yang memerlukan tindakan kebijaksanaan; (3) sistem hukum dan administrasi telah pula gagal dalam menyediakan institusi-institusi dan prosedur-prosedur yang menjamin anggota-anggota atau kelompok-kelompok masyarakat untuk melawan keabsahan keputusan-keputusan birokrasi sehubungan dengan alokasi sumber-sumber, dan sebaliknya sistem tersebut justeru memberikan fasilitas-fasilitas dan pelayanan kepada kelompok tertentu yang memegang hak dalam pembangunan. Kenyataan ini mencerminkan bahwa sistem hukum pada negara-negara dunia ketiga merupakan produk dari suatu proses sosial yang terjadi di atas sebuah struktur sosial tertentu sehingga hukum lebih merupakan super struktur yang wujud dan isinya sangat ditentukan oleh pola hubungan kekuasaan di antara infra struktur masyarakat.

Kajian-kajian hukum dan kekuasaan yang menempatkan kekuasaan sebagai faktor determinan atau sebagai suprastruktur, dan hukum sebagai subordinan adalah kajian-kajian kritis; sebuah kajian yang kurang mendapat tempat dalam studi-studi ilmu hukum dan studi-studi ilmu politik dan sosiologi di hampir semua perguruan tinggi di Indonesia. Itu sebabnya kajian atas fenomena sosial hukum di Indonesia selama ini banyak didominasi oleh kajian-kajian normatif dan fungsional yang melihat hukum dalam fungsinya sebagai aturan-aturan perilaku, yang mencari ketidakberfungsian hukum di dalam hukum dan aparat penegak hukum itu sendiri; terlepas dari sistem politik atau kekuasaan yang sedang berlangsung.

\section{Hukum dan Kekuasaan}

Salah satu fenomena menarik dalam hukum Indonesia selama pading tidak era Orde Baru yang lalu adalah tingginya produksi perundang-undangan dalam pelbagai bentuk, seperti UU, Peraturan Pemerintah, Peraturan Presiden, Instruksi Presiden, dan seterusnya. Secara normatif hal itu wajar-wajar saja, sebagaimana juga terjadi di negara-negara maju, tetapi fenomena di Indonesia menunjukkan hal yang berbeda karena ternyata derasnya produksi undang-undang atau peraturan-peraturan tersebut tidak memberi dampak yang cukup siqnifikan pada keadilan dan kesejahteraan rakyat. Yang terjadi sebaliknya; kehadiran UU yang banyak itu justru ketat dan kuat mengikat rakyat, tetapi lemah mengikat kekuasaan'.

Wajah kuasa Orde Baru cenderung mewujud menjadi "kekuasaan yang menindas" daripada "kekuasaan yang membebaskan". Kehadiran hukum bukan mewujudkan pencerahan, rasa aman, dan melindungi, tetapi justru terasa sangat menekan, membuat sumpek, mengungkung, dan membatasi ruang gerak. Dalam pandangan Roberto Mangabera Unger (1976) kenyataan hukum demikian itu merupakan efek logis dari "model hukum birokratik", yang menempatkan hukum

'Dalam istilah lain disebut model hukum represif, yaitu suatu model hukum yang bercirikan antara lain bahwa tujuan hukum adalah ketertiban; aturan-aturannya kasar dan terperinci, tetapi amat lemah mengikat pembuat hukum; sifat memaksa yang ekstensif; bertolak dari moralitas kriminal atau moralitas paksaan; ketaatan terhadap hukum bersifat tanpa syarat dan ketidaktaatan dianggap sebagai penyimpangan terhadap negara (Nonet \& Selznick 1978;79). 
Topik : Hukum Bukanlah Idealisasi Moral Masyarakat, Suparman Marzuki

tersubordinasi di bawah kepentingan birokrasi kekuasaan serta kepentingan dan institusi kapital. Kepentingan-kepentingan birokrasi untuk mewujudkan modernisasi secara cepat, misalnya, menjadi kekuatan superordinan di atas hukum. Kepentingankepentingan kapital-dalam rangka pertukaran kalkulatif di antara pelaku dunia hukum-potensial pula menjadi superordinan. Apalagi selama Orde Baru itu, jalinan kepentingan kapital (market) dan negara (state) begitu kental sehingga hukum menjadi rapuh, mengkret dan kalah tatkala harus berhadapan dengan kekuasaan birokratis dan kapital itu.

Dalam bahasa Amitai Etzioni, sebagaimana dikutif Eef Syaifullah Fatah (Kompas, 1998) kekuasaan semacam itu disebutnya sebagai "kekuasaan alienatif". Kekuasaan yang dibentuk oleh rekayasa struktur dan menghasilkan kepatuhan di balik tekanan. Apa yang disebut Etzioni sebagai "kekuasaan moral", yaitu kekuasaan yang dibangun di atas dasar konsensus normatif dan dipatuhi secara moral pun kurang terlihat. Kekuasaan alienatif tadi dimungkinkan pembentukannya bersamaan dengan terbentuknya "kekuasaan kalkulatif" yang dibentuk oleh kebutuhan modernisasi. Kekuasaan kalkulatif ini bersifat pragmatis: menghitung apa yang akan diberikan oleh sang penguasa berdasarkan berapa banyak yang akan diteri-ma. Kepatuhan pun bersifat pragmatis, tergantung pada pertukaran antara pemberian dengan penerimaan balik.

Praktik hukum dalam logika kekuasaan semacam itu -meminjam istilah Vinogradoff-terlibat dalam "give and take" atau logika jual beli. Dalam logika ini, pengadilan pun pada akhirnya menjadi "panggung sandiwara" yang mempertemukan para "pemain" (Polisi, jaksa, hakim, dan pengacara) untuk mementaskan sebuah lakon dalam cerita peristiwa hukum yang juga dalam logika jual beli. Praktik penegakan hukum dalam "kekuasaan alienatif" atau "kekuasaan kalkulatif "dalam birokrasi penegakan hukum yang tunduk pada "raison d"etat kekuasaan semacam itu sangat mencerminkan "moralisme" pusatpusat kekuasaan. Karena itu tepat apa yang dikemukakan penganut perspektif konflik, bahwa badan pengatur masyarakat, yaitu negara bukanlah alat yang mempunyai netralitas nilai, melainkan terlibat langsung dalam konflik. Penyebab konflik adalah ketidaksamarataan sosial, dan di dalam ketidakmerataan itulah hukum seringkali digunakan untuk keuntungan-keuntungan golongan berkuasa ${ }^{2}$, atau dalam dalam bahasa John Austin (1955) dilukiskannya sebagai: “.....a subordinate of subject judge is merely a minister. The portion of the soverign power which lies at his disposition is merely delegated. The rules which he makes derive their legal force from authority given by the state".

Dengan demikian, hukum tidak per-

2 Oleh sebab itu thema Orde Baru tentang "the rule of law" menjadi lumpuh dan utopis karena tidak mampu menanggulangi masalah-masalah dasar keadilan sosial sebab dirinya sendiri menjadi pendukung utama kekuasaan dan privelese, yang mengambil bagian dalam korupsi yang lebih dalam, dan yang lebih buruk lagi menjadi "musuh terselubung". Seperti dikatakan Paul Wolf $(1971 ; 132)$ bahwa kedaulatan hukum dalam negara modern tidak kurang sifat otoriternya dibandingkan kedaulatan manusia dalam masyarakat pra modern; hukum juga menegakkan ketidakmerataan kemakmuran dan kekuasaan; bahkan dengan cara-cara yang lebih rumit dan tidak langsung. 
nah mencerminkan atau menterjemahkan "volgeist" (the spirit of people) ${ }^{3}$ karena perspektif ini menganggap penciptaan dan penegakan hukum lebih baik dipahami sebagai berasal dari konflik-konflik yang inherent dalam ketidakmerataan distribusi kemakmuran, kekuasaan dan pengendalian sumber daya ekonomi.

Dalam salah satu penelitiannya, William J. Chambliss (1971) sudah membuktikan betapa konflik-konflik dalam kepentingan ekonomi khususnya, ikut melibatkan diri dalam proses pembuatan aturan-aturan hukum pidana. Chambliss mengambil contoh yang terjadi di sekitar proses pembuatan RUU Pencegahan dan Pengawasan Obat Bius di Amerika Serikat tahun 1970.

RUU itu disusun untuk mengendaljkan distribusi dan penggunaan obat-obat bius yang berbahaya, termasuk pula kemungkinan bagi alat-alat penegak hukum untuk memasuki pekarangan pribadi tanpa ijin dalam rangka menggeledah dan mencari adanya obat-obat bius yang berbahaya. Dari pembicaraan-pembicaraan dalam lembaga legislatif tampak bahwa pem-

${ }^{3}$ Berbeda dengan Perspektif struktural fungsional yang senantiasa memahami hukum sebagai perangkat aturan-aturan yang ditentukan oleh pembuat undang-undang dan lembaga-lembaga peradilan yang mencerminkan keyakinan-keyakinan dasar utama rakyat dalam suatu masyarakat. Pandangan ini juga melihat hukum adalah pemenuhan kebutuhan-kebutuhan pokok tertentu dalam masyarakat, tanpa merinci secara jelas siapa yang sesungguhnya dimaksud dengan "rakyat", yang konon kepentingan-kepentingan, pandangan-pandangan serta kebutuhankebutuhan terpuaskan oleh sistem hukum tersebut. buatan RUU untuk mengawasi penggunaan dan distribusi obat bius di Amerika Serikat diliputi oleh kenyataan bahwa para anggota legislatif tidak mau menandatangani suatu RUU yang berlawanan dengan kepentingan-kepentingan industri farmasi, kendatipun dihadapkan pada bukti-bukti bahwa industri inilah yang sesungguhnya harus bertanggung jawab atas penyebaran obat-obat bius. Peranan mereka yang berkepentingan dengan industri farmasi dalam pembuatan RUU itu terlihat jelas melalui lobi-lobi mereka kepada anggota parlemen. Akhirnya yang memperoleh penekanan dalam RUU itu adalah heroin, marijuana dan LSD, yang tidak merupakan bagian dari sistem keuntungan perusahaan-perusahaan farmasi. Karena itu menurut Chambliss, RUU ini merupakan perlindungan bagi industriindustri farmasi tertentu dari saingansaingan mereka; pengusaha-pengusaha tidak terorganisir yang memperjualbelikan jenis barang dagang yang sama; obat bius.

Pandangan Chambliss ini tampaknya juga dibangun berdasarkan perspektif dealektika Marx yang memandang konflikkonflik atau kontradiksi-kontradiksi dalam hubungan-hubungan ekonomi, sebagai akibat dari adanya kesenjangan dalam pemilikan-pemilikan sumber daya-sumber daya ekonomi sehingga kesempatan untuk survival secara ekonomis, serta kemampuan mengendalikan produksi akan jatuh ke tangan pemilik modal, termasuk dalam menentukan proses produksi dan penentuan pola konsumsi.

Para pemilik modal ini akan selalu memperoleh keuntungan dalam banyak sektor, termasuk kesempatan yang sangat luas di dalam memanfaatkan dan mendesakkan kepentingan-kepentingan hukum- 
nya. Oleh karena itu bagi Marx, perubahanperubahan sosial yang secara historis didorong atau dipicu oleh konflik ekonomi itu, menempatkan hukum sebagai pengemban amanat kepentingan ekonomi para pemilik modal. Hukum bukan sekali-kali model idealisasi moral masyarakat. Hukum kata Marx tidak lain adalah efifenomena, atau gejala sampingan yang berasal dari infrastruktur dan fungsi-fungsinya tidak lain adalah untuk menjaga kelangsungan cara produksi yang ada. Dengan demikian hukum dipandang berguna bagi klas yang berkuasa sebagai sarana penindasan dan sarana penipuan untuk menciptakan dan mempertahankan ilusi-ilusi yang mencitrakan seolah-olah nilai tatanan masyarakat yang ada lebih berharga daripada sebenarnya.

Perspektif dan sikap Marx terhadap hukum, secara lebih jelas dapat diikuti dalam sejumlah artikel Marx dalam menanggapi perdebatan di parlemen Rhein di Jerman mengenai undang-undang baru tentang pencurian kayu yang termuat dalam surat kabar Rheinische Zeitung pada tahun 1842 sebagaimana dikemukakan secara ringkas oleh Peters (1998) Pandangan Marx yang disajikan kembali oleh ahli sosiologi hukum Belanda ini memperlihatkan kurang lebih sebagai berikut:

Pertama, pemilikan pribadi sebagai alat pengucilan. Berdasarkan hak milik si pemilik tanah, orang miskin tidak diperbolehkan menikmati hasil tanah tersebut. Hak-hak adat tradisional seperti mengumpulkan kayu bakar dan memungut buah, kini ditafsirkan sebagai pelanggaran hak milik si pemilik, dan secara resmi disebut tindak pencurian. Padahal pencuri yang sesungguhnya adalah mereka yang merebut dari kaum miskin hak untuk melakukan itu. ${ }^{4}$

Kedua, undang-undang kapitalis melindungi nilai tukar di atas nilai pakai. llustrasi Marx tentang hal tersebut dikemukakan dalam buku Peters sebagai berikut:

\begin{abstract}
"Seorang wakil dari kota menaruh keberatan atas pasal-pasal dalam undang-undang baru yang menyatakan tindakan mengambil buahbuahan sebagai suatu pencurian. la khususnya membela anak-anak kaum miskin yang mengumpulkan buah-buahan itu untuk menambah sedikit pendapatan orang tua mereka. la mengemukakan bahwa tindakan ini sejak dulu kalau dizzinkan oleh pemiliknya dan telah menjadi suatu hak tradisional rakyat kecil, tetapi kenyataan ini kemudian disangkal oleh seorang wakil lain dengan alasan: di daerah tersebut buah-buahan itu telah dijualbelikan dan diekspor ke negeri Belanda dalam jumlah besar" (Peters, 1998)
\end{abstract}

Ketiga, UU kapitalis melanggar hak tradisional kaum miskin. Menurut Marx perumusan kembali hak-hak pemilikan tradisional dari mereka yang tidak memiliki harta benda, ditafsirkan oleh Marx sebagai suatu tindakan ketidakadilan sosial yang historis.

Keempat, hukum berdasarkan klas.

${ }^{4}$ Dalam perspektif sosiologi kritis apa yang disebut kejahatan dan apa yang bukan kejahatan, atau dalam bahasa hukum pidana, proyek kriminalisasi dan proyek dekriminalisasi adalah konstruksi kekuasaan. Jadi apa yang kejahatan dan apa yang bukan kejahatan adalah apa yang ditentukan oleh negara (state), bukan apa yang dinyatakan masyarakat. 
Topik : Hukum Bukanlah Idealisasi Moral Masyarakat. Suparman Marzuki

Dalam konteks ini Marx menilai bahwa UU mengenai pencurian kayu mengorbankan kepentingan-kepentingan umum demi kepentingan mereka yang mempunyai privelese. Di sini tidak terwujud "kekuasaan hukum" yaitu asas yang memperlakukan semua orang sederajat di muka hukum dan mengatur ketetapan-ketetapan bagi percaturan sosial antar mereka. Yang terjadi adalah bahwa hukum itu sendiri ditandai dengan ketimpangan sosial yang ada, dan telah dibuat menjadi sebuah sarana bagi kaum berada untuk mengamankan dan melegalisasi kedudukan mereka dengan merugikan kedudukan yang lain.

Kelima, Penyamaan yang keliru antara pengistimewaan orang kaya dan hak-hak kaum miskin dalam adat. Penghapusan aturan-aturan adat yang melimpahkan hak bagi kaum miskin pernah dianggap dapat dibenarkan, karena di bawah kekuasaan hukum, privelese kaum bangsawan dalam tradisi adat juga dihapus. Jadi hal itu dikemukakan sebagai suatu penerapan asas kesederajatan di muka hukum. Tetapi, seperti ditunjukkan oleh Marx, dari sudut kekuasaan hukum, antara hak-hak kaum bangsawan dan hakhak kaum miskin dalam tradisi adat, terdapat suatu perbedaan yang mendasar. Yang pertama merupakan antitesa dari konsep kekuasaan hukum itu sendiri dan rasionalitas hukum, sedang yang kedua tidak menyerupai kekuatan hukum, karena tidak mendapat pengakuan hukum formal. Dengan menyamakan kedua macam adat tersebut dan dengan menganggap adat kaum bangsawan dan adat kaum miskin sama-sama bertentangan dengan asas hukum yang rasional, maka perundangundangan modern menjadi sangat berat sebelah.

Kritik-kritik tajam Marx terhadap hukum positif atau dalam istilah lain sering disebut dengan hukum modern terkait dengan dominannya peran negara di dalam perumusan dan pelaksanaan penegakan hukum positif; sesuatu yang oleh Marx pasti menyembunyikan anasir-anasir kepentingan kekuasaan atau kepentingan kapital, baik di level konstruksi hipotetis pasal-pasal dalam undang-undang maupun di dalam pelaksanaannya, apalagi kata Marx, kebangkitan negara modern itu sebenarnya merupakan kemenangan kaum bangsawan atas kekuasaan yang dekaden.

Di dalam perspektif yang relatif sama Robert Lefcourt (1971) memberikan kritik yang tajam terhadap adigium hukum yang menyatakan "setiap orang sama di depan hukum" yang menurutnya hanya bermakna normatif saja karena dalam kenyataan dengan gampang bisa dilihat bahwa pengadilan-pengadilan pidana hampir secara ekskelusif cuma terarah pada kaum pekerja dan kaum miskin. Asas "equality before the law" dikritik sebagai bohong belaka karena seperti dikemukakan Ralf Dahrendof (1979) yang dikutif Mulyana W Kusumah (1981) bahwa mungkin ada "equality before the law", tetapi tidak akan pernah ada "equality after the law" karena setelah seseorang berurusan dengan hukum yang terjadi justru ketidaksamaan dalam hukum karena hukum kata Satjipto Raharjo (1980) dan William J. Chambliss (1971) hanya dapat djjangkau dan dinikmati oleh orang-orang berpunya saja, atau cenderung untuk dikenakan pada mereka yang berasal dari lapisan bawah. Dengan kata lain, semakin tinggi kedudukan sesuatu kelompok secara ekonomi maupun politik, semakin besar pula kemungkinannya bahwa pandangan serta kepentingannya akan tercermin di dalam hukum, dan Iebih dari itu pelaksanaan hukum dalam 
Topik : Hukum Bukanlah Idealisasi Moral Masyarakat, Suparman Marzuki

kenyataan akan jauh lebih aman terhadap kelompok masyarakat yang tidak memiliki kekuasaan daripada kepada yang sebaliknya .

Secara lebih. tegas William J. Chambliss (1975) menyatakan bahwa"... A consequence of the unequal ability of members of different social classes to reward the legal system is that at every step of the legal process the lower class persons is more likely to feel the sting of the law enforcement process".

Kecelakaan kapal Titanic pada tanggal 10 April 1912 telah digunakan oleh C.J.M. Schuyt (Mulyana: 1981) untuk menggambarkan betapa persamaan di depan hukum tidak lebih sekadar isapan jempol. Dalam kecelakaan laut paling mengerikan dalam sejarah pelayaran itu disebutkan bahwa penumpang wanita yang mati dari klas 3 sebanyak $45 \%$, dari klas 2 sejumlah $16 \%$ dan dari klas 1 sebesar $0,7 \%$, jadi karcis klas I ternyata tidak hanya memberi hak atas kamar yang nyaman saja, tetapi juga peluang dan kesempatan hidup yang berbeda. Inilah makna pandangan Daniel S. Lev yang menyatakan bahwa keadilan prosedural atau keadilan hukum hanya akan ada pada masyarakat yang telah mencapai keadilan substantif atau keadilan material, atau dengan kata lain bahwa keadilan hukum hanya dekat dengan seseorang atau kelompok orang yang sudah "survival" secara ekonomi dan atau politik, dan tidak akan pernah dirasakan oleh mereka yang miskin papa.

Membentangkan pandangan kritis terhadap hukum dalam realitas Indonesia dulu dan sekarang adalah relevan dan siqnifikan dalam rangka melacak dan membongkar ketidakadilan hukum Dalam kerangka ke depan, penting untuk melacak fenomena ketidakberpihakan hukum Indo- nesia kepada rakyat di dalam dua basis konseptual sistem hukum, yaitu ideologi Rule of Law (ROL) atau Rechstaat.

\section{ROL dan Rechstaat}

Ideologi Rule of law dan Rechstaat merupakan dua ideologi besar sistem hukum yang sering dipertukarkan begitu saja untuk menyebut negara hukum, dan setiap kali penyebutan itu dilakukan dikesankan kedua istilah itu tidak mengandung perbedaan, meskipun kedua konsep tersebut sebenarnya mengandung konotasi yang berbeda. Rule of law menunjuk kepada suatu susunan konstitusional dimana keabsahan tindakan-tindakan otoritas politik pemerintah, termasuk tindakantindakan legislatif, dapat diperiksa oleh peradilan yang bebas dan mandiri. Susunan ini didasarkan atas pembedaan antara aturan-aturan hukum konkret, sebagaimana dinyatakan dalam peraturan perundangundangan dan keputusan-keputusan pengadilan, serta prinsip-prinsip keadilan yang lebih tinggi dan lebih umum; atas dasar mana aturan-aturan hukum konkret dapat dikritik dan diverifikasi.

Sedangkan Rechstaat menunjuk kepada suatu negara dimana tindakantindakan otoritas politik pemerintah diberi bentuk hukum yang umum, dalam mana pembatasan kekuasaan dibuat dengan maksud membatasi luas lingkup kebijakan negara di dalam pelaksanaannya, sehingga penekanannya adalah pada keteraturan birokratis di dalam administrasi. Lebih lanjut, ideologi rule of law secara historis terbentuk di Inggris berkat pengaruh golongan menengah yang menguasai parlemen dan birokrasi kerajaan yang relatif lemah, sedang rechstaat Eropa Daratan tumbuh di wilayah kekuasaan 
birokrasi sentral yang kuat yang tidak dapat didobrak oleh kaum borjuasi, kecuali sekadar dapat diimbau agar memberi konsesi-konsesi. Sebagai akibatnya, kecenderungan prosedural pada sistem common law lebih menguntungkan pihak swasta (sipil) $^{5}$ daripada negara, sedang sebaliknya pada sistem civil law cenderung menguntungkan negara (Merryman, 1969). Dengan kata lain sistem common law lebih liberal daripada sistem civil law.

Dalam perspektif yang lain, mengikuti pendapat Weber, konsep patrimonial

${ }^{5}$ Dengan dasar ini pengaturan hak-hak warganegara dalam hukum material dan formal di banyak negara penganut ideologi ROL lebih cepat dan responship dibanding pada negara-negara penganut Recstaat. Tuntutan perubahan konstruksi hipotesis hukum formil Prancis, terutama setelah Montesquieu (16981755) menyatakan bahwa: "apabila warga negara tidak mempunyai perlindungan untuk membela diri dalam kesalahannya, maka dia tidak mempunyai perlindungan pula dalam mempertahankan kemerdekaannya". Telah menginspirasi pembaharuan aturan-aturn formal-prosedural hukum menyangkut 10 hal penting, yaitu (1) keterbukaan proses hukum; (2) bantuan penasihat hukum; (3) penghapusan memaksa tersangka untuk bersumpah; (4) persamaan posisi antara penyjdik/penuntut dengan tersangka/terdakwa; (5) pembatasan kekuasaan hakim pemimpin penyidikan; (6) motivasi yang jelas dalam putusan hakim;(7) penghapusan menyeluruh pemeriksaan dengan penyiksaan; (8) penghapusan peradilan pidana dalam bentuk khusus; (9) pengajuan ke muka pengadilan 24 jam setelah penangkapan dan dalam hal delik yang tidak serius pembebasan tersangka dengan jaminan; (10) kemungkinan untuk para saksi dalam hal dikonfrontasikan dengan tersangka, menarik kembali keterangan yang diberikan sebelumnya, tanpa ancaman pidana karena memberi kesaksian palsu. lebih berpengaruh dalam ideologi civil law daripada dalam ideologi common law. Karena adanya titik berat patrimonial dalam doktrin civil law yang mengutamakan lembaga birokrasi dan kepentingan negara. Para pemimpin Jepang, Muangthai, Turki dan Ethiopia misalnya, kesemuanya berpaling ke Eropa Daratan, tidak ke Inggris, ketika berupaya "memodernkan" sistem hukum mereka dengan meminjam bentukbentuk hukum Eropa. Sebaliknya, kelompok-kelompok liberal di negara-negara baru seperti Singapura, Malaysia, India cenderung berpaling ke praktek yang berlaku di Inggris dan Amerika untuk mendapatkan model-model kelembagaan dan doktrinal.

Kerunyaman hukum dan kekuasaan di Indonesia, tidak bisa dicari kesalahannya pada ideologi Rechstaat semata-mata, karena banyak negara yang memilih ideologi Recstaat tidak mengalami kekacauan hukum sebagaimana yang kita alami. Sistem hukum (civil law) yang kita anut yang menemukan jalinan kerja dan kaitan struktur yang pas dengan kekuasaan patrimonial, yang memang mengutamakan jaminan hukum atas peran negara dan birokrasi dibanding perhatian kepada hak-hak warga negara tampaknya merupakan perjumpaan yang menyulut kekacauan.

Keyakinan akan kebenaran pandangan ini akan semakin menguat apabila dikaitkan dengan paham integralistik Soepomo dan Soekarno sebagaimana tercermin dalam perdebatan mereka dengan Hatta dan Yamin mengenai perlu tidaknya Konstitusi 1945 menjamin hak-hak warganegara dalam hukum. Soepomo, yang oleh Marsilam Simanjuntak (1994) dipengaruhi paham totaliter Hegel dan Spinoza menyatakan bahwa negara tidak perlu menjamin HAM karena menurutnya: (i) menjamin hak 
Topik : Hukum Bukanlah Idealisasi Moral Masyarakat, Suparman Marzuki

asasi manusia dianggap berlebihan; (ii) dibayangkan berdampak negatif; dan (iii) sebagai hak-hak perorangan, selalu berada di bawah kepentingan bersama. HAM, kata Soepomo tidak membutuhkan jaminan Grund-und Freiheitsrechthe dari individu contra staat, oleh karena individu tidak lain ialah bagian organik dari staat yang menyelenggarakan kemuliaan staat, dan sebaliknya oleh politik yang berdiri di luar lingkungan suasana kemerdekaan seseorang. Negara kata Soepomo adalah susunan masyarakat yang integrai, anggota-anggota dan bagian-bagiannya merupakan persatuan masyarakat yang organis, persatuan yang' tidak mementingkan perseorangan dan mengatasi semua golongan, persatuan hidup berdasarkan kekeluargaan. (Buyung, 1995).

Sebagaimana Soepomo, Soekarno juga menganggap hak-hak asasi akan berdampak negatif karena memiliki kaitan dengan individualisme. Memberikan hakhak kepada warga negara bertentangan dengan kebebasan negara yang berdaulat. Soekarno bahkan dengan meyakinkan menyatakan bahwa jika negara ini dibangun dengan filsafat individualisme-liberalisme, maka yakinlah bahwa kita akan penuh dengan konflik.

Yamin dan Hatta memang berhasil mendesakkan beberapa pöint dan pasal yang menjamin perlidungan HAM dalam pembukaan dan batang tubuh UUD 1945, tetapi secara keseluruhan dapat dinyatakan bahwa sejak awal negara tidak memiliki komitment dasar yang jelas dan tegas untuk melindungi atau menjamin HAM, termasuk hak-hak warga negara. Sehingga oleh karena itulah upaya-upaya menterjemahkan serba sedikit jaminan UUD 1945 kedalam aturan-aturan materiil dan formil selalu mengalami kesulitan.

\section{Agenda Perubahan}

Dari penjelasan-penjelasan di atas menjadi jelas bahwa ketidakberpihakan hukum pada keadilan dan kesejahteraan rakyat sangat terkait dengan basis konseptual hukum yang kita anut serta kerangka ideologis negara integralistik yang memang condong pada penguatan negara dan birokrasi. Realitas sejarah ini sudah barang tentu akan mengabaikan hak-hak masyarakat. Oleh karena itu, yang diperlukan ke depan bukan sekadar mengubah aturan-aturan hukum agar berpihak pada keadilan sosial masyarakat tetapi suatu perubahan mendasar ke arah mendorong perubahan kekuasaan Patrimonial ke model kekuasaan Legal Rasional. Konsepsi legal memisahkan kekuasaan dari pribadi penguasa dan menempatkan kekuasaàn itu pada pranata otonom yang secara normatif ditegakkan dalam hukum yang impersonal. Kebebasan politik dan birokrasi, sebagai akibatnya, dibatasi oleh kepastian batas-batas hukum yang ditentukan oleh pranata undang-undang. Sudah barang tentu, yang demikian itu adalah bentuk ideal dan tidak terdapat dalam bentuknya yang murni dimanapun. Dalam kenyataan sistem politik, unsur-unsur patrimonial dan legal itu bercampur, walaupun semua masyarakat mempunyai jejakjejak patrimonial sedang beberapa di antaranya hanya sedikit mempunyai jejakjejak legal. Sekalipun demikian kita dapat membedakan misalnya, tertib politik dengan pengaruh patrimonial yang lebih kuat (Jerman, Jepang) atau yang lebih lemah (AS) sedang tertib politik yang pada asasnya bersifat legal atau tertib politik yang pada asasnya patrimonial dengan pengaruh legal yang kuat (India) atau yang sangat lemah (Indonesia). 
Gerakan hukum berupaya mengubah kerangka tersebut dari campuran yang bertitik berat pada kekuasaan patrimonial ke campuran yang bertitik berat pada kekuasaan legal. Agenda kedua adalah merubah tipe hukum, dari tipe hukum represif ke arah hukum yang otonom (autonomous law) dan sejauh mungkin mencapai tahapan hukum responsif (responsive law), dan dalam sistem terakhir inilah dimungkinkan negara mengakomodir seluas dan sebanyak mungkin kepentingan dan kebutuhan hukum masyarakat.

\section{Daftar Pustaka}

Chambliss, William \& Seidman. 1971. Law, Order, and Power, Reading, Massachusetts: Addison-Wesley Publishing Company.

Chambliss, William. 1975. Criminal Law in Action.

G. Nusantara, Abdul Hakim,1981. Beberapa Pemikiran Bantuan Hukum ke Arah Bantuan Hukum Struktural, Alumni, Jakarta.

Jhon Henry, Marryman, 1969. The Civil Law Tradition, Stanford Universuty Press, California.

Jhon Henry, Marryman, 1969. The Civil Law Tradition, Stanford Universuty Press, California.

Kelman, Mark. 1987. A Guide to Critical Legal Studies, Haevard University Press.
Lev S. Daniel. 1990. Hukum dan Polirik di Indonesia Kesinambungan dan perubahan, LP3ES, Jakarta.

Nasution, A. Buyung. 1995. Aspirasi Pemerintahan Konstitusional di Indonesia Studi Sosio Legal atas Konstituante 1956-1959, Grafiti, Jakarta.

Peters, A.A.G \& Siswosoebroto. 1988. Hukum dan Perkambangan Sosial Buku Teks Sosiologi Hukum, Sinar Harapan Jakarta.

Rahardjo, Satjipto. 1980. Hukum dan Masyarakat, Angkasa, Bandung.

Selznick, Philip. 1978. Law and Society in Transition: Toward Responsive Law, Russell Sage Foundation.

Simanjuntak, Marsilam. 1994. Pandangan Negara Integralistik, Grafiti, Jakarta,

Trubek, David M. 1972. Toward a Social Theory of Law: An Essay on the Study of Law and Development, The Yale Law Joumal Vol. 82.

Unger, Roberto Mangabera. 1976. Law in Modern Socety Toward a Criticism of Social Theory, The Free Press, A Divison of Macmillan Publishing Co, Inc, New York.

Unger M. Roberto. 1999. Gerakan Studi Hukum Kritis, Elsam, Jakarta.

W. Kusumah, Mulyana. 1981. Hukum dan HAM Suatu Pemahaman Kritis, Alumni, Bandung. 